\title{
FAKTOR-FAKTOR YANG MEMPENGARUHI KELUARGA DALAM PENERAPAN PERILAKU HIDUP BERSIH DAN SEHAT DI DESA PEMATANG LALANG
}

\author{
Nixson Manurung \\ Dosen Prodi S-1Keperawatan, STIKes Imelda, Jalan Bilal Nomor 52 Medan \\ Email : nixsonmanurung@gmail.com
}

\begin{abstract}
ABSTRAK
Kesehatan merupakan hal yang dicari oleh semua orang. Untuk mengetahui derajat kesehatan masyarakat desa dapat diperoleh melalui pendataan terhadap masyarakat desa tentang Perilaku Hidup yang Bersih dan Sehat (PHBS). Masalah sanitasi dasar sebagai bagian dari lingkungan masih merupakan masalah yang cukup besar di Indonesia, seperti terbatasnya ketersediaan dan akses air bersih, rendahnya akses sanitasi, masih rendahnya capaian rumah sehat dan lingkungan sehat, tingginya polusi udara akibat kebakaran hutan dan kendaraan, diperberat dengan masih rendahnya proporsi Rumah Tangga dengan PHBS baik. Penelitian ini bertujuan untuk mengetahui Gambaran Perilaku Keluarga Dalam Penerapan Hidup Bersih Dan Sehat Di Desa Pematang Lalang Kecamatan Percut Sei Tuan. Penelitian dalam studi ini menggunakan jenis penelitian Deskriptif. Tehnik sampling dalam penelitian ini adalah Insidental Sampling jumlah sampel yang terkumpul dalam penelitian ini berjumlah 68 keluarga di Desa Pematang Lalang. Tehnik Analisa data yang digunakan adalah editing, coding, sorting, entry data dan cleaning. Hasil penelitian mayoritas berpendidikan SD berjumlah 27 orang (39,7 $\%)$, SLTP berjumlah 28 orang (41,1\%), SLTA dan D3/S1/Sederajat masing-masing berjumlah 7 orang (10,1\%). Mayoritas memperoleh sumber informasi melalui Tenaga kesehatan berjumlah 22 orang (32,4\%), Kerabat/Keluarga berjumlah 18 orang (26,4\%), Media cetak berjumlah 12 orang (17,6\%) dan melalui Media elektronik berjumlah 16 orang (23,6\%), dari 68 responden mayoritas pekerjaannya bertani berjumlah 50 orang (73,5\%), Wiraswasta berjumlah 15 orang $(22,1 \%)$ dan PNS berjumlah 3 orang (4,4\%). Setelah data diolah menunjukkan bahwa tugas keluarga dalam Penerapan Perilaku Hidup Bersih Dan Sehat Di Desa Pematang Lalang Tahun 2018, mayoritas cukup diperoleh sebanyak 41 keluarga (60,3\%) dan minoritas kurang baik sebanyak 13 keluarga (19,1\%). Dari penelitian ini dapat disimpulkan bahwa tugas keluarga dalam penerapan perilaku hidup bersih dan sehat di Desa Pematang Lalang Kecamatan Percut Sei Tuan ini terkategori cukup dikaitkan dengan media informasi yang masih kurang ditandai dengan terbatasnya sarana pelayanan kesehatan dan jarak yang cukup jauh dari lokasi masyarakat yang berpusat di Puskesmas Tanjung Rejo untuk dipergunakan oleh desa-desa yang ada di kecamatan ini. Disini sangatlah penting peranan tenaga kesehatan untuk meningkatkan peran keluarga dalam penerapan perilaku hidup bersih dan sehat dengan memberikan pendidikan melalui penyuluhan tentang perilaku hidup bersih dan sehat.
\end{abstract}

Kata Kunci : Fungsi Keluarga, Perilaku, Hidup Bersih dan Sehat

PENDAHULUAN

Untuk mengetahui derajat kesehatan masyarakat desa dapat diperoleh melalui pendataan terhadap masyarakat desa tentang Perilaku Hidup yang Bersih dan Sehat (PHBS). Indeks Pembangunan Kesehatan Masyarakat menunjukkan persentase PHBS secara rata - rata nasional $35,7 \%$. Sedangkan rata-rata untuk Cuci Tangan Pakai Sabun (CTPS) hanya 24,5\%. Padahal PHBS dan CTPS merupakan upaya promotif dan preventif yang berperan penting mendukung terwujudnya Indonesia lebih sehat, (Indeks Pembangunan Kesehatan Masyarakat, 2010 dalam Putra, 2012).
Hasil survei awal yang dilakukan di Desa Pematang Lalang Kecamatan Percut Sei Tuan dengan luas desa : $2500 \mathrm{Ha}$ ( $850 \mathrm{Ha}:$ daerah Persawahan, $50 \mathrm{Ha}$ : daerah Pemukiman, 1600 : daerah Perkebunan), jumlah kepala keluarga \pm 351 KK. Pada umumnya lokasi pertanian, kandang ternak dan proses pembakaran sisa pertanian tidak jauh dari rumah ditambah masih terdapat balita yang belum lengkap imunisasinya, status gizi balita masih ditemukan ada yang buruk, dilihat dari daerah tersebut banyak sampah yang berserakan dan masyarakat kebanyakan mengolah sampah dengan cara dibakar saja sehingga lingkungan desa tersebut rentan terhadap sumber pencemaran sampah polusi udara.

Masalah sanitasi dasar sebagai bagian dari lingkungan masih merupakan masalah yang cukup besar di Indonesia, seperti terbatasnya 
ketersediaan dan akses air bersih, rendahnya akses sanitasi, masih rendahnya capaian rumah sehat dan lingkungan sehat, tingginya polusi udara akibat kebakaran hutan dan kendaraan, diperberat dengan masih rendahnya proporsi Rumah Tangga dengan PHBS baik. Menurut pusat promosi kesehatan, PHBS dapat mencegah terjadinya penyakit dan melindungi diri dari ancaman penyakit. Melihat data diatas maka penulis merasa tertarik untuk mengambil kasus yang berjudul "Gambaran Faktor-Faktor Yang Mempengaruhi Keluarga Dalam Penerapan Perilaku Hidup Bersih Dan Sehat Di Desa Pematang Lalang Tahun 2018".

\section{METODE}

Penelitian dalam studi ini menggunakan jenis penelitian Deskriptif yang bertujuan untuk membuat Gambaran Tugas Keluarga Dalam Penerapan Perilaku Hidup Bersih Dan Sehat Di Desa Pematang Lalang Tahun 2018. Penelitian ini dilaksanakan di Desa Pematang Lalang Kecamatan Percut Sei Tuan.

Jumlah sampel yang terkumpul dalam penelitian ini berjumlah 68 keluarga di Desa Pematang Lalang. Tehnik Analisa data yang digunakan adalah editing, coding, sorting, entry data dan cleaning.

\section{HASIL}

Tabel 1. Distribusi Frekuensi Responden Berdasarkan Tingkat Pendidikan Keluarga Dalam Penerapan Perilaku Hidup Bersih Dan Sehat Di Desa Pematang Lalang Tahun 2018.

\begin{tabular}{clcc}
\hline NO & Pendidikan & F & $\mathbf{( \% )}$ \\
\hline 1 & SD & 27 & 39,7 \\
\hline 2 & SLTP & 28 & 41,1 \\
\hline 3 & SLTA & 7 & 10,1 \\
\hline 4 & D3/S1/Sederajat & 7 & 10,1 \\
\hline & TOTAL & $\mathbf{6 8}$ & $\mathbf{1 0 0 \%}$ \\
\hline
\end{tabular}

Dari diatas dapat dilihat responden mayoritas berpendidikan SD berjumlah 27 orang $(39,7 \%)$, SLTP berjumlah 28 orang $(41,1 \%)$, SLTA dan D3/S1/Sederajat masing-masing berjumlah 7 orang $(10,1 \%)$.
Tabel 2. Distribusi Frekuensi Responden Berdasarkan Sumber Informasi Keluarga Dalam Penerapan Perilaku Hidup Bersih Dan Sehat Di Desa Pematang Lalang Tahun 2018

\begin{tabular}{clcc}
\hline No & Sumber Informasi & $\mathbf{F}$ & $\mathbf{( \% )}$ \\
\hline 1 & Tenaga kesehatan & 22 & 32,4 \\
\hline 2 & Kerabat/keluarga & 18 & 26,4 \\
\hline 3 & Media cetak & 12 & 17,6 \\
\hline 4 & Media elektronik & 16 & 23,6 \\
\hline & TOTAL & $\mathbf{6 8}$ & $\mathbf{1 0 0 \%}$ \\
\hline
\end{tabular}

Dari Tabel 2 diatas dapat dilihat 68 responden, mayoritas memperoleh sumber informasi melalui Tenaga kesehatan berjumlah 22 orang $(32,4 \%)$, Kerabat/Keluarga berjumlah 18 orang $(26,4 \%)$, Media cetak berjumlah 12 orang $(17,6 \%)$ dan melalui Media elektronik berjumlah 16 orang $(23,6 \%)$.

Tabel 3. Distribusi Frekuensi Responden Berdasarkan Pekerjaan Keluarga Dalam Penerapan Perilaku Hidup Bersih Dan Sehat Di Desa Pematang Lalang Tahun 2018.

\begin{tabular}{clcc}
\hline NO & Pekerjaan & F & $(\boldsymbol{\%})$ \\
\hline 1 & Bertani & 50 & 73,5 \\
\hline 2 & Wiraswasta & 15 & 22,1 \\
\hline 3 & PNS & 3 & 4.4 \\
\hline & TOTAL & $\mathbf{6 8}$ & $\mathbf{1 0 0 \%}$ \\
\hline
\end{tabular}

Dari Tabel 3 diatas dapat dilihat dari 68 responden mayoritas pekerjaannya bertani berjumlah 50 orang $(73,5 \%)$, Wiraswasta berjumlah 15 orang $(22,1 \%)$ dan PNS berjumlah 3 orang $(4,4 \%)$.

Tabel 4. Distribusi Frekuensi Responden Gambaran Tugas Keluarga Dalam Penerapan Perilaku Hidup Bersih Dan Sehat Di Desa Pematang Lalang Tahun 2018.

\begin{tabular}{lccc}
$\begin{array}{c}\text { Tugas } \\
\text { Keluarga }\end{array}$ & $\begin{array}{c}\text { Lebar } \\
\text { Interval }\end{array}$ & F & $\mathbf{( \% )}$ \\
\hline Baik & $35-45$ & 14 & 20,6 \\
\hline Cukup & $25-34$ & 41 & 60,3 \\
\hline Kurang & $15-24$ & 13 & 19,1 \\
\hline \multicolumn{2}{c}{ JUMLAH } & $\mathbf{6 8}$ & $\mathbf{1 0 0}$ \\
\hline
\end{tabular}

Pada Tabel 4 Setelah data diolah menunjukkan bahwa tugas keluarga dalam Penerapan Perilaku Hidup Bersih Dan Sehat Di Desa Pematang Lalang Tahun 2018, mayoritas cukup diperoleh sebanyak 41 keluarga $(60,3 \%)$ dan minoritas kurang baik sebanyak 13 keluarga $(19,1 \%)$.

\section{PEMBAHASAN}

Tugas Keluarga Dalam Penerapan Perilaku Hidup Bersih Dan Sehat yang baik hanya mencapai 14 keluarga (20,6 \%), Cukup sebanyak 41 keluarga $(60,3 \%)$ dan Kurang sebanyak 13 keluarga $(19,1 \%)$. 
Peneliti berasumsi bahwa hal ini dipengaruhi oleh mayoritas responden berpendidikan SD berjumlah 27 orang $(39,7 \%)$, SLTP berjumlah 28 orang $(41,1 \%)$, SLTA dan D3/S1/Sederajat masing-masing berjumlah 7 orang $(10,1$ $\%)$. faktor lain ditambahkan mayoritas pekerjaan responden adalah bertani berjumlah 50 orang $(73,5 \%)$, Wiraswasta berjumlah 15 orang $(22,1 \%)$ dan PNS berjumlah 3 orang $(4,4 \%)$.

Dari data dapat ditarik kesimpulan bahwa rendahnya tingkat pendidikan disertai taraf ekonomi yang rendah sangat besar pengaruhnya dalam Penerapan perilaku hidup bersih dan sehat hal senada dengan pendapat dari dr. Ina Aniati, bahwa perilaku hidup bersih dan sehat pada masyarakat pedesaan masih minim dimana taraf pendidikan dan pekerjaan yang rerata masih tergolong rendah, untuk itu dihimbau kepada masyarakat untuk menjaga ketahanan tubuhnya melalui konsumsi makanan bergizi dan melindungi diri dari bahaya polusi, dan bagi para keluarga yang memiliki balita agar menghindarkan balitanya dari asap rokok atau pun polusi berlebih.

Peneliti dapat menyimpulkan bahwa tugas keluarga dalam penerapan perilaku hidup bersih dan sehat di Desa Pematang Lalang Kecamatan Percut Sei Tuan ini terkategori cukup dikaitkan dengan media informasi yang masih kurang ditandai dengan terbatasnya sarana pelayanan kesehatan dan jarak yang cukup jauh dari lokasi masyarakat yang berpusat di Puskesmas Tanjung Rejo untuk dipergunakan oleh desa-desa yang ada di kecamatan ini. Disini sangatlah penting peranan tenaga kesehatan untuk meningkatkan peran keluarga dalam penerapan perilaku hidup bersih dan sehat dengan memberikan pendidikan melalui penyuluhan tentang perilaku hidup bersih dan sehat.

\section{KESIMPULAN}

Tugas keluarga dalam penerapan perilaku hidup bersih dan sehat di desa Pematang Lalang Tahun 2018 dalam kategori cukup, hal ini dipengaruhi oleh tingkat yang mayoritasnya berpendidikan SD berjumlah 27 responden. Faktor lain ditambahkan mayoritas pekerjaan responden adalah bertani selain itu faktor yang paling berpengaruh besar yakni minimnya responden yang memperoleh sumber informasi kesehatan melalui tenaga kesehatan dikarenakan terbatasnya sarana pelayanan kesehatan dan jarak yang cukup jauh dari lokasi masyarakat yang berpusat di Puskesmas Tanjung Rejo untuk dipergunakan oleh Desa-Desa yang ada di Kecamatan ini.

\section{SARAN}

Sebaiknya keluarga waspada karena saat ini rawan penyakit anak seperti ISPA (Infeksi Saluran Pernapasan Akut), diare, demam berdarah dan penyakit lainya yang dapat timbul akibat kurangnya perilaku hidup bersih dan sehat memasuki musim kemarau, serta lebih giat untuk bertanya langsung kepada petugas kesehaan bagaimana yang sebenarnya penerapan perilaku hidup bersih dan sehat yang baik.

\section{DAFTAR PUSTAKA}

Ananto, Purnomo. (2006). UKS : Usaha Kesehatan Sekolah dan Madrasah Ibtidaiyah. Bandung: Yrama Widya.

Arikunto, Suharsimi. (2006). Prosedur Penelitian Suatu Pendekatan Praktik. Jakarta: Rienika Cipta.

Azwar, S. (2009). Sikap Manusia, Teori dan Pengukurannya. Yogyakarta :Pustaka Pelajar offset.

Destya. (2009). Faktor-faktor Yang Berhubungan Dengan Motivasi Keluarga Untuk Melakukan PHBS. http://etd.eprints.ums.ac.id/pdf. Diunduh 20 Oktober 2010.

Departemen Kesehatan RI. (1997). Buku Panduan Manajemen Penyuluhan Kesehatan Masyarakat Tingkat Propinsi. Jakarta: Depkes RI.

Departemen Kesehatan RI. (2002). Panduan Manajemen PHBS Menuju Kabupaten/Kota Sehat. Pusat Promosi Kesehatan. Jakarta: Depkes RI.

Departemen Kesehatan RI. (2007). Perilaku Hidup Bersih Sehat. http://repository.usu.ac.id/bitstream/12345 6789/16933/4/Chapter\%20I.pdf. Diunduh 19 Oktober 2010.

Hartanto. (2009). Membudayakan Gerakan Cuci Tangan. http://suaramerdeka.com Diunduh 01 November 2010. 
Hidayat, A. Aziz Alimul. (2007). Metode Penelitian Keperawatan dan Teknik Analisis. Jakarta: Salemba Medika.

Jariston. (2009). Pengetahuan, Sikap dan Tindakan Perilaku Hidup Bersih dan Sehat Anak-anak di Yayasan Panti Asuhan Rapha-El Simalingkar Medan. http://suaramerdeka.com Diunduh 01 November 2010.

Jawapos. (2010). Perilaku Hidup Bersih dan Sehat. http://www.medical jour nal.co.cc/2010/03/perilaku-hidupbersih-dan-sehat.html. Diunduh 19 Oktober 2010.

Mubarak, Wahid Iqbal, dkk. (2006). Ilmu Keperawatan Komunitas. Jakarta: CV Sagung Seto.

Muri'fah dan Hardiyanto W. (1992). Pendidikan Kesehatan. Jakarta: Departemen Pendidikan dan Kebudayaan.

Niken. (2010). SAP Cara Mencuci Tangan.

http://rentalhikari.wordpress.com. Diunduh 01 November 2010.

Nursalam. (2003). Konsep Dan Penerapan Metodologi Penelitian Ilmu Keperawatan. Jakarta: Salemba Medika.

Nursalam. (2008). Konsep dan Penerapan Metodologi Penelitian Ilmu Keperawatan Edisi 2. Jakarta: Rineka Cipta.

Notoatmodjo, S. (2000). Pendidikan Promosi dan Perilaku Kesehatan. Jakarta: FKM UI.

Notoatmodjo, S. (2002). Metode Penelitian Kesehatan. Jakarta: Rineke Cipta.

Notoatmodjo, S. (2003). Pendidikan dan Perilaku Kesehatan. Jakarta: Rhineka Cipta.

Notoatmodjo, S. (2005). Metodelogi Penelitian Kesehatan. Jakarta: Rineka Cipta.

Notoatmodjo, S. (2007). Promosi Kesehatan dan Ilmu Perilaku. Jakarta: Rineke Cipta.

Sayetno. (2010). Pelaksanaan PHBS di Sekolah. (2010). http://www.askepaskeb/pelaksanaan-phbs-di sekolah. html\#axzz141T8FQfY. Diunduh 01 November 2010.

Potter P, Griffin PA. (2005). Buku ajar fundamental keperawatan, Volume
I, alih bahasa Asih Y, et.al., Edisi 4. Jakarta: EGC.

Sugiyono. (2005). Statistik Untuk Peneliti an. Bandung: Alfabeta.

Walgito, Bimo. (2004). Pengantar Psikologi Umum.Yogyakarta: Anndi Offset.

Wijono. (1999). Tujuan Pembangunan Kesehatan Indonesia Sehat 2010. http://www.tugaskuliah.info/2010/06/tuju an-pembangunan-kesehatan indonesia.html. Diunduh 04 November 2010. 